\title{
Komunikacja kliniczna - porównanie opinii lekarzy i pacjentów
}

\section{Clinical communication - a comparison of patients' and doctors' opinions}

\author{
Krzysztof Sobczak $^{1}$, Katarzyna Leoniuk', Leszek Pawłowski², Natalia Spolak ${ }^{3}$ \\ ${ }^{1}$ Gdański Uniwersytet Medyczny, Zakład Socjologii Medycyny i Patologii Społecznej, ul. Tuwima 15, 81-210 Gdańsk \\ ${ }^{2}$ Gdański Uniwersytet Medyczny, Zakład Medycyny Paliatywnej, ul. Dębinki 2, 80-211 Gdańsk \\ ${ }^{3}$ Gdański Uniwersytet Medyczny, Klinika Alergologii, ul. Dębinki 2, 80-211 Gdańsk \\ $\bowtie$ ksobczak@gumed.edu.pl
}

\begin{abstract}
Introduction: The main aim of the research was to assess medical communication from the point of view of clinicians and their patients.

Materials and methods: 100 doctors and 378 patients were included in the study. Original tools prepared by the interdisciplinary team were used during the research. The research tools consisted of closed questions concerning the quality assessment of medical communication, and they were the same for both groups. Discontinuous variables as well as the statistical heterogeneity of groups were analysed with Pearson's $\chi^{2}$ test, assessing the value $\mathrm{p}<0.05$ as significant.

Results: The mean score for satisfaction with doctor-patient communication given by patients in a 1-11 point scale was 6.79 (median 8.0 points). Objections were raised mostly by women with higher education, aged 30-40 years. Only one out of two
\end{abstract}

patients declared that he/she was continuously updated with medical information by the attending physician. Although all the surveyed doctors considered that the clinical information given by them was clear and accurate, $38.8 \%$ of patients said that they were left with doubts after conversations with their doctors. As many as $77.4 \%$ of patients said that they were not sufficiently informed about possible complications and therapeutic risks, while $96.9 \%$ of doctors claimed that they provided this kind of information.

Conclusions: Analyses show that patients were satisfied with the quality of medical communication. On the other hand, the study revealed a deficit in the relationship between patients and doctors, which was caused by the fact that patients were not informed about the diagnostic and therapeutic process.

Keywords: clinician-patient communication; doctor-patient relationship.

\begin{abstract}
ABSTRAKT
Wstęp: Celem badań była ocena komunikacji medycznej z punktu widzenia lekarzy klinicznych i ich pacjentów.

Materiały i metody: Badaniem objęto 100 lekarzy i 378 pacjentów klinicznych. Zastosowano autorskie narzędzie przygotowane przez interdyscyplinarny zespół specjalistów. Narzędzia badawcze składały się z analogicznych dla obu grup pytań zamkniętych dotyczących oceny jakości komunikacji medycznej. Do analizy zmiennych nieciągłych oraz statystycznej niejednorodności grup zastosowano test $\chi^{2}$ Pearsona, przyjmując za istotną statystycznie wartość $\mathrm{p}<0,05$.

Wyniki: Średnia ocena poziomu zadowolenia pacjentów z komunikacji z lekarzami w 11-stopniowej skali wyniosła 6,79, zaś mediana 8,0. Statystycznie najwięcej zastrzeżeń zgłaszały kobiety z wykształceniem wyższym w przedziale wiekowym
\end{abstract}

30-40 lat. Zaledwie co drugi pacjent zadeklarował, że otrzymywał na bieżąco informacje medyczną od lekarza prowadzącego. Chociaż wszyscy zapytani lekarze uznali, że przekazują informacje w sposób zrozumiały i precyzyjny, to 38,8\% pacjentów ujawniło, że pozostało z wątpliwościami po rozmowie ze swoim lekarzem. Aż 77,4\% pacjentów stwierdziło, że nie zostali w sposób wystarczający poinformowani o możliwych powikłaniach i ryzyku terapeutycznym, chociaż 96,9\% lekarzy zadeklarowało przekazanie tego rodzaju wiadomości.

Wnioski: Profil analiz wskazał na zadowalającą ocenę jakości komunikacji medycznej. Jednocześnie pacjenci sygnalizowali istnienie istotnego deficytu w zakresie bieżącego otrzymywania informacji o procesach diagnostyczno-terapeutycznych. Słowa kluczowe: komunikacja z pacjentem; komunikacja kliniczna; relacja lekarz-pacjent.

\section{WSTĘP}

Jednym z podstawowych narzędzi pozyskiwania informacji klinicznych jest właściwa komunikacja między lekarzem i pacjentem. Jej jakość warunkuje całokształt oddziaływania medycznego oraz wpływa na poziom satysfakcji. Jeżeli statystycznie jeden lekarz w ciągu swojej kariery medycznej przeprowadza ok. 150 tys. wywiadów, to postępowanie to staje się najczęściej stosowaną procedurą medyczną [1]. Badania przeprowadzane w krajach anglosaskich wskazują, że to, jakim

językiem posługuje się lekarz, zbierając informację o stanie zdrowia pacjenta, istotnie warunkuje sukces terapeutyczny [2]. Podobne wnioski dotyczą form przekazywania informacji zwrotnej pacjentom. Właściwa komunikacja w tym zakresie przyczynia się do pogłębienia zaangażowania pacjenta w proces terapeutyczny. Powoduje wzrost zaufania do lekarza [3, 4], determinuje nie tylko wyniki leczenia [5], ale przekłada się także na poziom satysfakcji pacjenta z usług medycznych [6, 7], hamuje wypalenie zawodowe lekarzy [8] oraz podnosi ich poziom poczucia własnej efektywności [9]. Wykazano także, 
że ma istotny wpływ na redukcję ryzyka wnoszonych pozwów sądowych i zgłaszanych roszczeń [10]. Lekarze z dobrze rozwiniętymi kompetencjami miękkimi są w stanie szybciej wykrywać problemy medyczne, a tym samym skuteczniej zapobiegać ich niekorzystnym następstwom. Skutkuje to lepszymi wynikami w leczeniu, wysokim poziomem satysfakcji pacjentów, niższymi kosztami opieki oraz poszerzeniem wiedzy zdrowotnej pacjentów [11].

Istotność wniosków otrzymywanych z badań prowadzonych w krajach anglosaskich oraz ich praktyczne implikacje coraz częściej dostrzegane są także w Polsce. Punktem wyjścia dla możliwości polepszenia skuteczności przepływu informacji medycznej, co zaczyna być podkreślane także w rodzimej literaturze, jest uznanie, że paternalistyczny model relacji lekarz-pacjent nie sprzyja efektywnej komunikacji [12]. Coraz liczniejsze badania wskazują na konieczność podkreślenia tych aspektów interakcji, które stanowią nie tylko o satysfakcji pacjentów, ale także determinują skuteczność oddziaływania klinicznego. Reformacja asymetrii relacji lekarz-pacjent $\mathrm{z}$ odniesienia paternalistycznego w stronę modelu partnerskiego (dialogicznego) odkrywa z kolei konieczność zagospodarowania nowych przestrzeni wsparcia pacjenta. Gwarantować ma nie tylko właściwą realizację funkcji informacyjnej (art. 31, ust. 1-5 Ustawy o zawodach lekarza i lekarza dentysty z dnia 5 grudnia 1996 r.), ale także zindywidualizowane wsparcie instrumentalno-rzeczowe i emocjonalne $[13,14]$. To z kolei wymusza konieczność wprowadzenia zmian w treściach kształcenia studentów kierunków medycznych i stażystów, tak aby dyskurs biomedyczny został skutecznie poszerzony o praktyczne wiadomości z zakresu psychologii i socjologii medycyny [15].

Celem prezentowanych badań była ocena komunikacji medycznej z punktu widzenia lekarzy klinicznych i ich pacjentów. Z jednej strony badano, jak pacjenci postrzegają zachowanie doświadczonych lekarzy, którzy oprócz funkcji terapeutycznej odpowiadają w szpitalach klinicznych także za praktyczną naukę i socjalizację zawodową studentów oraz młodych lekarzy. Z drugiej strony analizowano to, czy wiedza, doświadczenie oraz wysokie kwalifikacje lekarzy przekładają się na satysfakcję ich pacjentów w zakresie kontaktów interpersonalnych i komunikacji. Przyjęto także, że uzyskane wyniki mogą stać się podstawą do określenia pewnych założeń edukacyjnych skutkujących podniesieniem jakości interakcji między lekarzami i pacjentami.

\section{MATERIAŁY I METODY}

Badanie przeprowadzono między lutym a czerwcem $2015 \mathrm{r}$. na terenie Uniwersyteckiego Centrum Klinicznego w Gdańsku (UCK). Pierwszą grupę badanych stanowili lekarze $(n=100)$ zatrudnieni w 12 klinikach o profilach zabiegowych i zachowawczych. Drugą grupę badanych tworzyli pacjenci tych klinik (n = 378), którzy ukończyli 18. r.ż., byli w chwili badania komunikatywni oraz przygotowywani do opuszczenia szpitala. Dobór lekarzy i pacjentów spełniających powyższe kryteria był losowy (tab. 1). Na realizację badań uzyskano zgodę
Niezależnej Komisji Bioetycznej ds. Badań Naukowych przy Gdańskim Uniwersytecie Medycznym, zgodę dyrektora UCK oraz kierowników poszczególnych klinik.

W badaniu użyto dwóch autorskich kwestionariuszy ankiety. Narzędzia badawcze charakteryzujące się wysokim stopniem standaryzacji składały się z analogicznych pytań adresowanych do lekarzy i pacjentów oraz z różniących się w obu wersjach pytań metryczkowych. Ankiety zostały przygotowane przez interdyscyplinarny zespół, w skład którego weszli specjaliści z zakresu socjologii medycyny, bioetyki, prawa medycznego i psychologii. Główne problemy podjęte w badaniu dotyczyły ocen wybranych elementów jakości komunikacji medycznej występującej w relacji między lekarzem i pacjentem.

W analizie statystycznej uwzględniono zmienne społeczno-demograficzne, takie jak: płeć, wiek, stan cywilny oraz miejsce zamieszkania (pacjenci). Ponadto w przypadku lekarzy pozyskano dodatkowe dane dotyczące zmiennych zawodowych, takich jak: staż i miejsce pracy, stanowisko oraz tytuł zawodowy lub naukowy. Natomiast w przypadku pacjentów dodatkowo uwzględniono zmienne dotyczące częstotliwości hospitalizacji. Uzyskane wyniki poddano analizie statystycznej przy użyciu programu SPSS v. 23. W analizie zależności pomiędzy zmiennymi nieciągłymi oraz statystycznej niejednorodności grup zastosowano test $\chi^{2}$ Pearsona. Za statystycznie istotne przyjęto różnice dla $\mathrm{p}<0,05$.

\section{WYNIKI}

\section{Rozmowa diagnostyczna i terapeutyczna}

Przypomnijmy, że zastosowane w badaniu pytania dotyczące komunikacji medycznej umożliwiają porównanie odpowiedzi uzyskanych w obu badanych grupach. W pierwszej kolejności zapytano lekarzy i pacjentów o ocenę interakcji mających miejsce podczas wywiadów, rozmów diagnostycznych lub terapeutycznych.

W rezultatach uzyskano zbieżne odpowiedzi dotyczące częstotliwości: stawiania przez lekarza pytań zamkniętych, posługiwania się czytelnym i zrozumiałem językiem oraz wyjaśniania niezrozumiałych dla pacjenta terminów medycznych. Różnice między odpowiedziami twierdzącymi lub przeczącymi lekarzy i pacjentów okazały się nieznaczne oraz nieistotne statystycznie. Natomiast istotne rozbieżności dotyczyły pytań otwartych. Podczas rozmowy stawianie tego rodzaju komunikatów zadeklarowało 97\% lekarzy. Z kolei zaledwie 77,6\% pacjentów oceniło, że tego rodzaju pytanie zostało zadane im przez lekarza. Oznacza to, że co piąty pacjent stwierdził, że podczas rozmowy z lekarzem nie poproszono go, aby samodzielnie opisał stan swojego zdrowia czy swobodnie wypowiedział się w kwestiach terapeutycznych. Analogiczne rozbieżności uzyskano w pytaniu dotyczącym próby ustalenia, czy pacjent posiada jakiekolwiek wątpliwości lub pytania w temacie odbywającego się spotkania z lekarzem. Dokładnie 92\% lekarzy zadeklarowało, że z reguły próbuje ustalić, czy ich pacjenci posiadają jakieś wątpliwości lub niejasności dotyczące przekazywanych informacji. Faktu tego nie 
TABELA 1. Charakterystyka respondentów

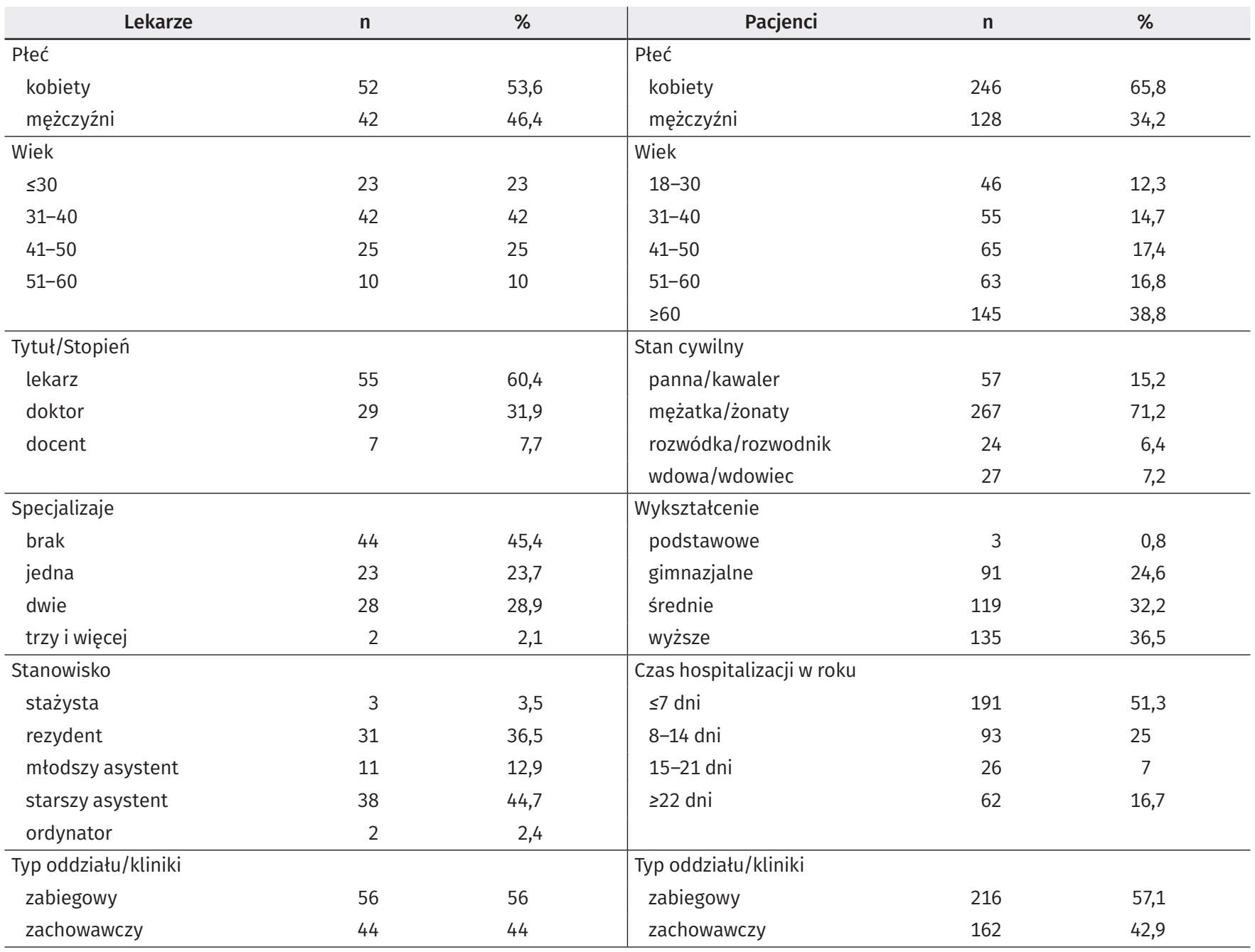

potwierdziło 18,3\% zapytanych pacjentów. Wszyscy lekarze zadeklarowali, że odpowiadają na pytania i wyjaśniają wszelkie wątpliwości natury medycznej. Z kolei 38,8\% pacjentów uznało, że nie uzyskali oczekiwanych informacji i pozostali z wątpliwościami po rozmowie z lekarzem. Istotnym problemem okazała się być także informacja dotycząca możliwych powikłań i ryzyka związanego z leczeniem. Aż 96,9\% lekarzy zadeklarowało, że tego typu wiadomości z reguły dostarcza swoim pacjentom. Fakt ten potwierdziło 77,4\% pacjentów, czyli niemal co czwarty nie uzyskał tego rodzaju informacji.

Biorąc pod uwagę typy klinik, podzielono badanych na dwie grupy; pierwszą stanowili pacjenci i lekarze z oddziałów o profilach zabiegowych, zaś drugą lekarze i pacjenci z oddziałów zachowawczych. W wyniku analizy stwierdzono istotne statystycznie różnice w odpowiedziach obu badanych grup. Pytania otwarte częściej zadawali lekarze na oddziałach zachowawczych $(88,7 \%)$ niż na zabiegowych $(76,4 \%$ dla $\mathrm{n}=478$; $\left.\chi^{2}=11,625 ; \mathrm{df}=1 ; \mathrm{p}=0,001\right)$. Podobnie było $\mathrm{w}$ przypadku dopytywania pacjentów o to, czy wszystkie przekazane przez lekarza informacje były zrozumiałe. Częściej taka sytuacja miała miejsce na oddziałach o profilach zachowawczych $(88,6 \%)$ niż zabiegowych $\left(80,4 \%\right.$ dla $\left.n=478 ; \chi^{2}=5,663 ; \mathrm{df}=1 ; \mathrm{p}=0,017\right)$. Kryterium przyjętego podziału klinik okazało się być także istotne w analizie dotyczącej częstotliwości udzielania przez lekarzy odpowiedzi na wszelkie pytania i wątpliwości pacjentów. W przypadku oddziałów zachowawczych pozytywnie oceniło ten element komunikacji 76,6\% pacjentów i lekarzy, zaś $64,2 \%$ w przypadku oddziałów zabiegowych $\left(\chi^{2}=8,167\right.$; $\mathrm{df}=1 ; \mathrm{p}=0,004)$. Można zatem stwierdzić, iż typ oddziału/kliniki wpływa na częstotliwość stosowania badanych elementów komunikacji lekarz-pacjent, przy czym więcej szczegółowych informacji na pytania pacjentów przekazywanych jest na oddziałach zachowawczych niż na oddziałach zabiegowych.

Istotne rozbieżności pojawiły się w wynikach analiz obu grup badanych dotyczących poczucia intymności i swobodnej wymiany informacji. W opinii $84,5 \%$ pacjentów takie warunki zostały im zagwarantowane. Dokładnie $15,5 \%$ pytanych przyznało, że odczuwało w tej kwestii istotny dyskomfort. W odpowiedzi lekarzy zaledwie 27,5\% przyznało, że organizuje tak przestrzeń spotkania z pacjentem, aby wyeliminować udział osób trzecich oraz zapewnić poczucie nieskrępowania i intymności. Zdecydowanie negatywnie w tej kwestii wypowiedziało się zaledwie 2\% zapytanych medyków. Aż 70,4\% wskazało, że ich starania w tej kwestii uzależnione są od zewnętrznych możliwości (np. możliwości odbycia rozmowy z pacjentem w pokoju badań).

Porównując odpowiedzi uzyskane w obu badanych grupach, można stwierdzić, iż we wszystkich przypadkach 
lekarze częściej niż pacjenci pozytywnie oceniali zastosowanie poszczególnych elementów rozmowy: częstotliwości stosowania przez lekarza pytań otwartych, informowania o konsekwencjach wybranego leczenia, dopytywania i odpowiadania na wątpliwości pacjenta oraz zachęcania do współdecydowania w procesie terapeutycznym. Uzyskane różnice okazały się istotne statystycznie (tab. 2). Można zatem stwierdzić, iż oceny lekarzy i pacjentów są na podobnym poziomie.

Biorąc pod uwagę wszystkich badanych, zaobserwowano statystycznie istotne różnice w odpowiedziach kobiet i mężczyzn (n = 478). Rozbieżności dotyczyły ocen częstotliwości stosowania w rozmowie czytelnego i zrozumiałego języka, zadawania pytań otwartych, wyjaśniania terminów medycznych, stawiania pytań potwierdzających rozumienie przekazywanych informacji oraz kreowania warunków przestrzennych zapewniających poczucie intymności i swobodną wymianę informacji. W przypadku wszystkich wymienionych elementów mężczyźni częściej niż kobiety potwierdzali ich stosowanie przez lekarza prowadzącego (tab. 3).

\begin{tabular}{|c|c|c|}
\hline \multirow{2}{*}{$\begin{array}{c}\text { Czy z reguty w rozmowie } \\
\text { z pacjentem lekarz stosowat.../ } \\
\text { Czy z reguty w rozmowie } \\
\text { z pacjentem stosujesz... }\end{array}$} & \multicolumn{2}{|c|}{$\begin{array}{l}\text { Odpowiedzi twierdzące (tak)* } \\
\text { n (\%) }\end{array}$} \\
\hline & lekarze & pacjenci \\
\hline \multirow{2}{*}{ Pytania otwarte } & $97(97)$ & $278(77,7)$ \\
\hline & \multicolumn{2}{|c|}{$X^{2}=19,717 ; d f=1 ; p<0,01$} \\
\hline \multirow{2}{*}{$\begin{array}{l}\text { Pytania dotyczące posiadanych } \\
\text { wątpliwości na temat przekazanych } \\
\text { informacji medycznych }\end{array}$} & $92(92)$ & $299(81,7)$ \\
\hline & \multicolumn{2}{|c|}{$X^{2}=6,177 ; d f=1 ; p=0,01$} \\
\hline \multirow{2}{*}{$\begin{array}{l}\text { Komunikaty zachęcające } \\
\text { do współdecydowania o leczeniu }\end{array}$} & $90(90)$ & $268(74,2)$ \\
\hline & \multicolumn{2}{|c|}{$X^{2}=11,212 ; d f=1 ; p=0,001$} \\
\hline \multirow{2}{*}{$\begin{array}{l}\text { Komunikaty związane } \\
\text { z przekazaniem informacji } \\
\text { o możliwych konsekwencjach } \\
\text { leczenia }\end{array}$} & $95(96,9)$ & $281(77,4)$ \\
\hline & \multicolumn{2}{|c|}{$x^{2}=19,568 ; d f=1 ; p<0,01$} \\
\hline
\end{tabular}

* Respondenci mieli do wyboru dwie odpowiedzi - „tak” lub „nie”. W tabeli umieszczono dane dotyczące tylko odpowiedzi twierdzących dla całej badanej zbiorowości (obu podgrup badanych - lekarzy i pacjentów).

TABELA 3. Badane elementy relacji lekarz-pacjent a płeć $(n=478)$

\begin{tabular}{|c|c|c|}
\hline \multirow{2}{*}{$\begin{array}{c}\text { Czy z reguły w rozmowie lekarz } \\
\text { stosowat.../ } \\
\text { Czy z reguły w rozmowie } \\
\text { z pacjentem stosujesz... }\end{array}$} & \multicolumn{2}{|c|}{$\begin{array}{c}\text { Odpowiedzi twierdzące (tak)* } \\
\text { n (\%) }\end{array}$} \\
\hline & kobieta & mężczyzna \\
\hline \multirow{2}{*}{ Pytania otwarte } & $224(78,6)$ & $145(87,3)$ \\
\hline & \multicolumn{2}{|c|}{$x^{2}=5,402 ; d f=1 ; p=0,020$} \\
\hline \multirow{2}{*}{ Czytelny i zrozumiały język } & $274(94,5)$ & $169(98,8)$ \\
\hline & \multicolumn{2}{|c|}{$x^{2}=5,419 ; d f=1 ; p=0,020$} \\
\hline \multirow{2}{*}{ Wyjaśnienia terminów medycznych } & $236(81,9)$ & $151(88,8)$ \\
\hline & \multicolumn{2}{|c|}{$x^{2}=3,862 ; d f=1 ; p=0,049$} \\
\hline \multirow{2}{*}{$\begin{array}{l}\text { Pytania potwierdzające } \\
\text { zrozumienie przekazywanych } \\
\text { informacji }\end{array}$} & $236(81,9)$ & $149(88,7)$ \\
\hline & \multicolumn{2}{|c|}{$X^{2}=4,538 ; d f=1 ; p=0,033$} \\
\hline \multirow{2}{*}{$\begin{array}{l}\text { Warunki stwarzające poczucie } \\
\text { intymności i swobodną wymianę } \\
\text { informacji }\end{array}$} & $207(70.4)$ & $131(76.6)$ \\
\hline & \multicolumn{2}{|c|}{$X^{2}=12,122 ; d f=2 ; p=0,002$} \\
\hline
\end{tabular}

* Respondenci mieli do wyboru dwie odpowiedzi - „tak” lub „nie”. W tabeli umieszczono dane dotyczące tylko odpowiedzi twierdzących dla całej badanej zbiorowości (obu podgrup badanych - lekarzy i pacjentów).

\section{Przekazywanie informacji medycznej}

Kolejnym ważnym elementem określającym postępowanie medyczne, tak w aspekcie psychospołecznym, jak i prawnym, jest forma oraz czas dostarczania przez lekarza informacji zwrotnej pacjentowi. W tych kontekstach zapytano lekarzy i pacjentów o oceny sposobów dostarczania wiadomości wynikających z postępowania terapeutycznego.

Najwięcej badanych przyznało, że zdarzyła im się sytuacja, w której otrzymali bądź przekazali informację o chorobie dopiero pod koniec pobytu w placówce leczniczej, mimo że pewne informacje diagnostyczne były dostępne lekarzowi wcześniej. Zdarzenie takie zgłosiło 20,3\% pacjentów i aż 40\% lekarzy.

Zbieżne wyniki uzyskano (11,1\% lekarzy i 14,4\% pacjentów) w trakcie analizy sytuacji, w której lekarz w ogóle nie udzielił ustnej informacji pacjentowi o stanie jego zdrowia, a jedynie przekazał wypis ze szpitala. Jedynie w tym przypadku różnice nie okazały się istotne statystycznie (tab. 4).

TABELA 4. Częstotliwość występowania zachowań niekorzystnych w ocenach lekarzy i pacjentów

\begin{tabular}{|c|c|c|}
\hline \multirow{2}{*}{$\begin{array}{c}\text { Czy zdarzyła się sytuacja, w której } \\
\text { lekarz.../ } \\
\text { Czy zdarzyło się w rozmowie } \\
\text { z pacjentem... }\end{array}$} & \multicolumn{2}{|c|}{$\begin{array}{l}\text { Odpowiedzi twierdzące (tak)* } \\
\text { n (\%) }\end{array}$} \\
\hline & lekarze & pacjenci \\
\hline \multirow{2}{*}{$\begin{array}{l}\text { Stosowat/-ć wobec pacjenta } \\
\text { komunikaty w formie bezosobowej }\end{array}$} & 16 (16) & $33(8,9)$ \\
\hline & \multicolumn{2}{|c|}{$x^{2}=4,305 ; d f=1 ; p=0,03$} \\
\hline \multirow{2}{*}{$\begin{array}{l}\text { Udzielił/-ć pacjentowi informacji } \\
\text { o jego stanie zdrowia i leczeniu } \\
\text { dopiero na koniec pobytu } \\
\text { w placówce }\end{array}$} & $40(40)$ & $74(20,3)$ \\
\hline & \multicolumn{2}{|c|}{$x^{2}=16,505 ; d f=1 ; p<0,01$} \\
\hline \multirow{2}{*}{$\begin{array}{l}\text { Nie poinformował/-ć pacjenta } \\
\text { o możliwości kontynuowania } \\
\text { diagnostyki i leczenia, mimo } \\
\text { że takie świadczenia są wskazane } \\
\text { i dostępne w innych placówkach }\end{array}$} & $8(8)$ & $60(17,4)$ \\
\hline & \multicolumn{2}{|c|}{$x^{2}=5,282 ; d f=1 ; p=0,02$} \\
\hline
\end{tabular}

* Respondenci mieli do wyboru dwie odpowiedzi - „tak” lub „nie”. W tabeli umieszczono dane dotyczące odpowiedzi „tak”. Pozostali badani, nieuwzględnieni w tabeli, wybrali odpowiedź "nie”.

Warto zauważyć, iż wszystkie wyniki zamieszczone w tabeli 4 różnią się w sposób zasadniczy. I tak niespełna 2-krotnie częściej lekarze deklarowali używanie komunikatów w formie bezosobowej (16\% lekarzy i 8,9\% pacjentów) oraz przekazywanie informacji o stanie zdrowia pacjenta dopiero w momencie opuszczania placówki. Natomiast brak informacji o możliwości kontynuowania diagnostyki i leczenia zgłosiło 17,4\% pacjentów, mimo że zaledwie 8\% lekarzy przyznało, że takiej informacji nie przekazało.

Ważnym aspektem komunikacji medycznej jest bezzwłoczne przekazywanie informacji dotyczących: planowania i wyników badań, postępów w leczeniu lub ich braku. W ocenie lekarzy do najczęściej przekazywanych na bieżąco informacji medycznych należą te dotyczące wyników badań i postępów terapeutycznych. Ponad połowa medyków (60\%) zadeklarowała, że przekazuje tego typu informacje zawsze i na bieżąco. Natomiast pacjenci ocenili $(63,2 \%)$, iż bieżąca informacja pochodząca od lekarza dotyczyła zaplanowanych badań. Otrzymanie 
TABELA 5. Porównanie opinii lekarzy i pacjentów w kwestii przekazywania informacji medycznych $(n=478)$

\begin{tabular}{|c|c|c|c|c|c|c|}
\hline \multirow{2}{*}{$\begin{array}{c}\text { Czy lekarz na bieżąco informuje } \\
\text { pacjenta } 0 . .\end{array}$} & \multicolumn{2}{|c|}{$\begin{array}{c}\text { "Tak, zawsze" } \\
\text { n (\%) }\end{array}$} & \multicolumn{2}{|c|}{$\begin{array}{l}\text { "Nie, nigdy" } \\
\text { n (\%) }\end{array}$} & \multicolumn{2}{|c|}{$\begin{array}{c}\text { "W zależności od sytuacji” } \\
\text { n (\%) }\end{array}$} \\
\hline & pacjenci & lekarze & pacjenci & lekarze & pacjenci & lekarze \\
\hline Wynikach badań & $170(46,4)$ & $60(60)$ & $42(11,2)$ & $0(0)$ & $155(42,3)$ & $40(40)$ \\
\hline Planowanych badaniach & $232(63,2)$ & $35(35)$ & $28(7,6)$ & $0(0)$ & $108(29,2)$ & $65(65)$ \\
\hline Postępach terapeutycznych & $177(50)$ & $60(60)$ & $38(10,7)$ & $0(0)$ & $139(39,3)$ & $40(40)$ \\
\hline Braku w postępach terapeutycznych & $124(37)$ & $35(35)$ & $54(16,1)$ & $0(0)$ & $157(46,9)$ & $65(65)$ \\
\hline
\end{tabular}

aktualnej informacji na temat postępów terapeutycznych zadeklarował zaledwie co drugi pacjent (tab. 5).

Analizując rozkład odpowiedzi zaprezentowanych w tabeli 5, należy zauważyć, iż jedynie pacjenci wybierali możliwość „nie, nigdy”. Istotnym jest podkreślenie, że lekarze częściej niż chorzy uwarunkowywali przekazanie informacji od sytuacji.

Zestawiając otrzymane odpowiedzi ze zmiennymi społeczno-demograficznymi, stwierdzono, że poziom wykształcenia ma statystycznie istotne znaczenie dla oceny sposobu otrzymywania informacji. Różnice dotyczyły informacji o wynikach badań $\left(\chi^{2}=18,34 ; \mathrm{df}=2 ; \mathrm{p}<0,001\right)$, planowanych badaniach $\left(\chi^{2}=25,115 ; \mathrm{df}=2 ; \mathrm{p}<0,001\right)$ oraz braku postępów terapeutycznych $\left(\chi^{2}=13,069 ; \mathrm{df}=2, \mathrm{p}<0,001\right)$. We wszystkich tych kategoriach osoby z wyższym wykształceniem rzadziej niż pozostałe wybierały odpowiedź twierdzącą („tak, zawsze”), a w porównaniu z nimi osoby o niższym poziomie wykształcenia co najmniej 2-krotnie częściej wybierały odpowiedz zdecydowanie przeczącą („nie, nigdy”).

Warto dodać, iż jedynie w przypadku przekazywania na bieżąco informacji o wynikach badań stwierdzono istotne statystycznie różnice w wypowiedziach lekarzy i pacjentów przebywających na oddziałach zabiegowych i zachowawczych. Możliwość „tak, zawsze” wybrało 59,7\% pacjentów i lekarzy z oddziałów zachowawczych i 41,2\% z oddziałów zabiegowych (dla $\left.\mathrm{n}=466 ; \chi^{2}=11,625 ; \mathrm{df}=2 ; \mathrm{p}=0,001\right)$.

\section{Ogólna ocena komunikacji}

W badaniu poproszono pacjentów $(\mathrm{n}=378)$, aby w oparciu o 11-stopniową skalę (gdzie o oznaczało ocenę najniższą, a 10 najwyższą) ocenili ogólny poziom jakości komunikacji ze swoim lekarzem prowadzącym. Średnia uzyskanych ocen wyniosła 6,79, zaś mediana 8,0. Niespełna co trzeci pacjent (30\%) wskazał na maksymalny poziom zadowolenia, drugie tyle $(32,1 \%)$ uznało jakość komunikacji za dobrą i bardzo dobrą. Stanowisko zdecydowanie negatywne w swoich ocenach zajęło $7,9 \%$ pytanych pacjentów, natomiast $12,7 \%$ oceniło poziom komunikacji na bardzo niski i niski. Dokładnie 17,3\% oceniło poziom komunikacji z lekarzem prowadzącym jako średni.

W ocenie tej zauważono istotne statystycznie różnice $\mathrm{w}$ wypowiedziach kobiet i mężczyzn $\left(\chi^{2}=13,460 ; \mathrm{df}=4\right.$; $p=0,009$ dla $n=328$ ). Średni poziom zadowolenia 2-krotnie częściej wskazywały kobiety (21,8\%) niż mężczyźni $(9,4 \%)$. Ponadto kobiety częściej wybierały ocenę najniższą i niską. Negatywnie kontakt z lekarzem prowadzącym oceniło 23,2\% badanych kobiet i 16,2\% mężczyzn. Natomiast ocenę wysoką i najwyższą częściej wskazywali pacjenci płci męskiej (74\%) niż żeńskiej (54\%). Można więc stwierdzić, że kobiety są bardziej krytyczne w ocenie komunikacji z lekarzem prowadzącym, co może wynikać z wyższych oczekiwań w tym zakresie lub z przywiązywania większej wagi do bezpośredniego kontaktu w trakcie hospitalizacji.

Drugą zmienną istotną statystycznie, wpływającą na ocenę komunikacji z lekarzem, okazał się być poziom wykształcenia pacjentów $\left(\chi^{2}=18,286 ; \mathrm{df}=4 ; \mathrm{p}=0,001\right.$ dla $\left.\mathrm{n}=325\right)$. Na oceny niską i najniższą 2-krotnie częściej wskazywali pacjenci z wyższym wykształceniem $(29,1 \%)$ niż pozostali $(14,9 \%)$. Oceny wysokie i najwyższe częściej wystawiały osoby mające ukończone studia wyższe $(66,9 \%)$ w porównaniu do pacjentów z pozostałym rodzajem wykształcenia (56,4\%). Można zatem stwierdzić, iż osoby z wykształceniem wyższym są bardziej krytyczne w ocenie satysfakcji z komunikacji z lekarzem w porównaniu do osób z wykształceniem średnim i niższym.

Trzecią zmienną niezależną, wpływającą na ocenę komunikacji lekarz-pacjent, był wiek $\left(\chi^{2}=11,523 ; \mathrm{df}=4 ; \mathrm{p}=0,021\right.$ dla $\mathrm{n}=328)$. Pacjenci do 40. r.ż. prawie 2-krotnie częściej (30,2\%) wybierali ocenę niską i najniższą niż ci, którzy ukończyli 40 lat (16,8\%). Różnice widoczne są również w przypadku wyboru oceny średniej, którą wskazało $21,5 \%$ osób przed 40. r.ż. oraz $15,7 \%$ osób starszych. Natomiast oceny wysoką i najwyższą częściej wybierali przedstawiciele starszej grupy wiekowej $(67,7 \%)$ niż respondenci przed 40. r.ż. $(48,4 \%)$. Zatem bardziej krytyczni w ocenach okazali się być pacjenci młodsi.

\section{DYSKUSJA}

Wyniki badań wskazują, że lekarze używali z reguły właściwego języka, dostosowując jego formę do możliwości percepcyjnych pacjentów. Styl komunikacji miał charakter z reguły spersonalizowany, język był czytelny i zrozumiały, a spotkania zdaniem pacjentów przeważnie odbywały się w aurze poszanowania ich intymności oraz w warunkach umożliwiających odbycie swobodnej rozmowy. Istotne były także dane wskazujące na właściwe przeprowadzenie wywiadu lekarskiego oraz dostarczanie informacji zwrotnej pacjentom, które miały z reguły charakter pewny i sprawdzony. Ogólny poziom oceny komunikacji między lekarzem prowadzącym w opinii zapytanych pacjentów można więc określić jako zadowalający. Do mankamentów w tym aspekcie można zaliczyć istotne rozbieżności między deklaracjami lekarzy a opiniami pacjentów w kwestii używania terminów medycznych, które okazały się być dla pacjentów niezrozumiałe. Dokładnie 20\% zapytanych pacjentów przyznało, że doświadczyło takiej sytuacji, jednocześnie wszyscy lekarze zadeklarowali, że wyjaśniali terminologię 
medyczną, która mogła być niezrozumiała. Przyczyny tych rozbieżności mogą być różne i należałoby je zweryfikować w kolejnych badaniach.

Do drugiej warstwy deficytów ujawnionych w rezultatach podjętych badań niewątpliwie należy supozycja pacjenta istniejąca w relacji między nim a lekarzem. Wydaje się, że z reguły lekarze oczekują, aby pacjent nie pozostawał autonomicznie aktywny w relacji diagnostyczno-terapeutycznej. Wskazuje na to kilka przesłanek.

Po pierwsze fakt, że prawie co trzeci pacjent podkreślił brak szansy swobodnego wyrażenia swojego zdania na temat dolegliwości czy choroby, z jaką się zgłosił do kliniki. W tym zakresie lekarze przyznają prawie jednomyślnie, że taką możliwość swoim pacjentom stwarzali.

Po drugie, aż 18,3\% pacjentów zadeklarowało, że nie zostało zapytanych przez lekarzy o to, czy istnieją jakiekolwiek kwestie medyczne wymagające wyjaśnienia. Jednocześnie należy zauważyć istotny dysonans między ocenami uzyskanymi w obu zbiorowościach dotyczącymi poziomu świadomości sytuacji klinicznej, w jakiej znaleźli się pacjenci. Prawie $40 \% \mathrm{z}$ nich zadeklarowało, że miało pytania i wątpliwości co do swojej sytuacji zdrowotnej, przy czym wszyscy zapytani lekarze odpowiedzieli, że na pytania i wątpliwości pacjentów zawsze odpowiadają. Czy zatem lekarze w wystarczającym stopniu zachęcają pacjentów do dzielenia się swoimi wątpliwościami, czy może zbyt często zakładają brak takowych bez odpowiedniej weryfikacji i zachęcania pacjenta do otwartości?

Po trzecie z wypowiedzi dwóch grup respondentów wynika, że informacja medyczna nie jest dostarczana pacjentom na bieżąco. Lekarze preferują przekazywanie informacji medycznych na koniec pobytu w placówce leczniczej. Warte podkreślenia jest to, że ponad 10\% lekarzy przyznało, że zdarza im się nie przekazywać swoim pacjentom bezpośrednio wiadomości o wynikach leczenia, a zamieszczać te informacje jedynie w wypisie. Taki stan rzeczy potwierdziło ponad $14 \%$ pacjentów.

Z powyższych wyników można wnioskować o fakcie występowania w relacjach klinicznych między lekarzami a pacjentami pewnej asymetrii ról. Ta relacja w swojej istocie nosi znamiona paternalistycznej, co objawia się brakiem aktywności pacjenta, w tym swobodnego i bieżącego dostępu do informacji medycznej. Rezultatem takiego odniesienia jest pacjent „łatwiejszy” $\mathrm{i}$ „sprawniejszy” w postępowaniu diagnostyczno-terapeutycznym. Wydaje się, iż ujawnione deficyty, które uwidaczniają się w postawach lekarzy, mogą prowadzić do podtrzymania asymetrii w relacji lekarz-pacjent kosztem preferowanego modelu partnerskiego.

Na podstawie zebranych i opracowanych danych własnych stwierdzono, że statystycznie to kobiety, osoby z wykształceniem wyższym, mieszczące się w przedziale wiekowym miedzy 18. a 40. r.ż., częściej negatywnie oceniały jakość komunikacji i relacje interpersonalne z lekarzami. Grupy młodszych i dobrze wykształconych pacjentów częściej niż pozostali oczekują relacji z lekarzem opartej na współpracy, z możliwością pełnienia aktywnej roli w procesie leczniczym. Uzyskane rezultaty są zbieżne z wynikami innych, szczątkowych badań realizowanych w przedmiotowym temacie, niezależnie od tego, czy dotyczyły one pacjentów hospitalizowanych w publicznych placówkach służy zdrowia [16], czy też pacjentów przychodni placówek niepublicznych [17].

W związku z uzyskanymi w niniejszej pracy wynikami właśnie aspekt dynamiki relacji lekarz-pacjent wymaga istotnej reformacji. Jak wynika z badań, zagwarantowanie aktywnej roli pacjentowi skutkuje jego większym zaangażowaniem w proces leczenia [18]. Jest również parametrem istotnie podnoszącym poziom satysfakcji z otrzymanej opieki $[4,7,19]$. Z kolei brak udziału pacjenta w podejmowaniu decyzji, np. dotyczących przyjmowanych leków, skutkuje pojawieniem się działań niepożądanych, takich jak nieprzestrzeganie zaleceń, które prowadzą do pogorszenia stanu zdrowia [20]. Od strony pacjentów brak możliwości wyrażenia swojego zdania, poczucie deficytu w zakresie posiadania bieżących informacji o wynikach badań i postępach w leczeniu skutkuje nieufnością wobec lekarzy, subiektywnym spadkiem poczucia bezpieczeństwa i gorszą oceną rezultatów terapeutycznych. Właściwa komunikacja, szczególnie w świecie nieustannie wzrastającego poziomu złożoności wiedzy i nowoczesnej technologii, jest dzisiaj bardziej pożądana niż kiedykolwiek przedtem [21].

\section{WNIOSKI}

Badania ujawniły, że mimo dość dobrze ocenianej przez pacjentów i lekarzy wzajemnej komunikacji, występują pewne deficyty w zakresie ilości, czasu i charakteru dostarczanych informacji medycznych. Stąd sugestia, aby lekarze praktykujący w szpitalach zwracali większą uwagę na potrzebę włączania pacjentów w procesy diagnostyczno-terapeutyczne poprzez indywidualizację i personalizację kontaktów z pacjentami w taki sposób, aby:

1) unikać terminologii medycznej niezrozumiałej dla pacjenta,

2) poświęcać adekwatną ilość czasu na bieżące wyjaśnianie zagadnień związanych z prowadzonym leczeniem,

3) wyjaśniać w sposób niebudzący wątpliwości problemy diagnostyczne i terapeutyczne,

4) zapewniać pacjentom możliwości swobodnego opisu dolegliwości,

5) zachęć pacjentów do otwartego wyrażania posiadanych przez nich wątpliwości,

6) zwrócić uwagę na konieczność bieżącego przekazywania informacji diagnostycznych (zlecanych badań, ich celu oraz przebiegu) i terapeutycznych (omówienia wyników badań).

\section{PIŚMIENNICTWO}

1. Impact of Communication in Healthcare. Institute for Healthcare Communication. http://healthcarecomm.org/about-us/impact-of-communication-in-healthcare/ (4.05.2016).

2. Marcinowicz L, Chlabicz S, Bielska DE, Czachowski S, Domalewska A, Ołtarzewska AM, et al. Jak skutecznie rozmawiać z pacjentem i jego rodziną? Praktyka lekarza rodzinnego. Warszawa: Wydawnictwo Lekarskie PZWL; 2014. p. 7-30 
3. Burge S, White D, Bajorek E, Bazaldua O, Trevino J, Albright T, et al. Correlates of medication knowledge and adherence: findings from the residency research network of South Texas. Fam Med 2005;37(10):712-8.

4. Golin C, DiMatteo MR, Duan N, Leake B, Gelberg L. Impoverished diabetic patients whose doctors facilitate their participation in medical decision making are more satisfied with their care. J Gen Intern Med 2002;17(11):857-66

5. Zolnierek KB, Dimatteo MR. Physician communication and patient adherence to treatment: a meta-analysis. Med Care 2009;47(8):826-34.

6. Beck RS, Daughtridge R, Sloane PD. Physician-patient communication in the primary care office: a systematic review. J Am Board Fam Pract 2002;15(1):25-38.

7. Clark PA. Medical practices' sensitivity to patients' needs. Opportunities and practices for improvement. J Ambul Care Manage 2003;26(2):110-23.

8. Suchman AL, Roter D, Green M, Lipkin M. Physician satisfaction with primary care office visits. Collaborative Study Group of the American Academy on Physician and Patient. Med Care 1993;31(12):1083-92.

9. Ammentorp J, Sabroe S, Kofoed PE, Mainz J. The effect of training in communication skills on medical doctors' and nurses' self-efficacy. A randomized controlled trial. Patient Educ Couns 2007;66(3):270-7.

10. Makoul G, Arntson P, Schofield T. Health promotion in primary care: physician-patient communication and decision making about prescription medications. Soc Sci Med 1995;41(9):1241-54.

11. Clack GB, Allen J, Cooper D, Head JO. Personality differences between doctors and their patients: implications for the teaching of communication skills. Med Educ 2004;38(2):177-86.

12. Kazimierczak A. Wpływ komunikacji z personelem medycznym na doświadczanie choroby przez pacjentów. Homo Communicativus 2011;1(6):21-37.
13. Maciąg A, Sakowska I. Rola i prawa pacjenta w obszarze jakości usług zdrowotnych. Studia i Materiały - Wydział Zarządzania Uniwersytetu Warszawskiego 2006;1(1):50-62.

14. Czerw A, Religioni U, Matuszna A, Lesiak K, Olejnik A, Śniadała D. Zasady skutecznej komunikacji w placówkach medycznych. Hygeia Public Health 2012;47(3):247-53.

15. Deręgowska J. Profesjonalna komunikacja w opiece zdrowotnej jako element wsparcia pracowników zawodów medycznych i pacjentów - oczekiwania i potrzeby. Studia Eduk 2015;35:349-66.

16. Wroński K, Bocian R, Depta A, Cywiński J, Dziki A. Opinie pacjentów na temat modelu paternalistycznego w relacji lekarz-pacjent: prawne aspekty autonomii pacjenta w opiece zdrowotnej. Nowotwory 2009;59(4):266-73.

17. Wiklińska M, Kuźmińska A. Czynniki wpływające na satysfakcję pacjenta. Studia i Materiały Polskiego Stowarzyszenia Zarządzania Wiedzą 2011;55:265-77.

18. Edwards A, Elwyn G. Inside the black box of shared decision making: distinguishing between the process of involvement and who makes the decision. Health Expect 2006;9(4):307-20.

19. Wanzer MB, Booth-Butterfield M, Gruber K. Perceptions of health care providers' communication: relationships between patient-centered communication and satisfaction. Health Commun 2004;16(3):363-83.

20. Britten N, Stevenson FA, Barry CA, Barber N, Bradley CP. Misunderstandings in prescribing decisions in general practice: qualitative study. BMJ 2000;320(7233):484-8

21. Warmuz-Stangierska I, Horst-Sikorska W. Ogólne zasady komunikacji między pacjentem i lekarzem. Forum Med Rodz 2007;1(1):58-68. 